\title{
Pengaruh Perilaku Kepemimpinan Visioner Kepala Sekolah, Budaya Kerja Dan Iklim Kerja Terhadap Performance Guru SMP Negeri Di Kabupaten Pohuwato
}

\author{
Triso Suleman, Ansar, Arifin Suking \\ Program Studi Magister Administrasi Pendidikan \\ Universitas Negeri Gorontalo, 2019 \\ Trisosuleman68@Gmail.Com
}

Received: 13 August 2021; Revised: 02 October 2021; Accepted: 14 December 2021

DOI: http://dx.doi.org/10.37905/aksara.8.1.303-312.2022

\begin{abstract}
Abstrak
Penelitian ini bertujuan untuk mengetahui (1) pengaruh perilaku kepemimpinan visioner kepala sekolah terhadap performance guru. (2) pengaruh budaya kerja terhadap performance guru. (3) pengaruh iklim kerja terhadap performance guru. (4) pengaruh perilaku kepemimpinan visioner kepala sekolah terhadap iklim kerja. (5) pengaruh budaya kerja terhadap iklim kerja. Metode penelitian yang digunakan yakni metode kuantitatif. Teknik pengumpulan data menggunakan kuesioner. Teknik analisis data yang digunakan adalah analisis jalur dengan menggunakan bantuan program SPSS. Hasil penelitian ini menunjukan bahwa (1) Perilaku kepemimpinan visioner kepala sekolah berpengaruh langsung positif dan signifikan terhadap performance guru SMP Negeri di Kabupaten Pohuwato. (2) Budaya kerja berpengaruh langsung positif dan signifikan terhadap performance guru SMP Negeri di Kabupaten Pohuwato. (3) Iklim kerja berpengaruh langsung positif dan signifikan terhadap performance guru SMP Negeri di Kabupaten Pohuwato. (4) Perilaku kepemimpinan visioner kepala sekolah berpengaruh langsung positif dan signifikan terhadap iklim kerja SMP Negeri di Kabupaten Pohuwato. (5) Budaya kerja berpengaruh langsung positif dan signifikan terhadap iklim kerja SMP Negeri di Kabupaten Pohuwato.
\end{abstract}

Kata kunci: Performance, Kepemimpinan Visioner, Budaya Kerja, Iklim Kerja

\section{PENDAHULUAN}

Performance guru dalam melaksanakan peran dan tugasnya di sekolah khususnya dalam proses pembelajaran dalam konteks sekarang ini memerlukan pengembangan dan perubahan kearah yang lebih inovatif. Fakta di lapangan menunjukkan bahwa masih terdapat beberapa guru yang kurang rajin dalam mengajar, hal ini dikarenakan mereka telah mempunyai gaji yang cukup sehingga mulai jarang untuk bekerja. Selain itu banyak dijumpai guru yang kurang profesional, hal tersebut dapat dilihat dari perilaku guru yang membolos pada jam pelajaran, jadwal mengajar dari guru yang tidak terencana, malas ketika hendak mengajar. Perilaku-perilkau tersebut menunjukkan kinerja guru yang rendah

Secara umum masih rendahnya performance yang dilakukan oleh guru dalam proses pembelajarn. Hal ini dapat dilihat dari (1) masih terdapat beberapa guru yang belum mampu memahami karakteristik siswa, (2) materi yang diajarkan kepada siswa kurang memotivasi siswa untuk berkonsentrasi dalam proses pembelajaran (3) masih terdapat beberapa guru yang belum menyiapkan kelengkapan dalam proses belajar mengajar (4) kurangnya penanganan yang serius terhadap siswa yang nilainya dibawah rata-rata. (5) minimnya pengetahuan guru dalam penggunaan media pembelajaran (6) masih banyaknya guru yang masih melanggar tata tertib sekolah khususnya pada kedisiplinan waktu kerja. 
Dari beberapa kendala serta kekurangan yang dapat menurunkan performance guru tersebut, perlu kiranya segera ditangani karena dengan lebih meningkatkan performance guru, sehingga mutu pendidikan akan tercapai lebih baik. Perilaku kepemimpinan visioner kepala sekolah, iklim kerja, budaya kerja sebagai faktor yang berpengaruh terhadap performance guru dan hal ini sejalan dengan apa yang diutarakan oleh Davis (2007: 276) yang menyatakan bahwa performance guru dipengaruhi oleh tiga faktor yaitu: faktor-faktor yang mempengaruhi performance guru dapat berasal dari dalam individu itu sendiri seperti motivasi, keterampilan, dan juga pendidikan. Ada juga faktor dari luar individu seperti iklim kerja, budaya kerja, tingkat gaji, kepemimpinan kepala sekolah, dan lain sebagainya

\section{METODE PENELITIAN}

Penelitian ini dilaksanakan di SMP Negeri di Kabupaten Pohuwato. Populasi adalah seluruh guru SMP Negeri di Kabupaten Pohuwato yang berjumlah 329 guru. Penentuan besarnya sampel penelitian menggunakan Nomogram Hary King" sebanyak 144 orang guru.

Berdasarkan tipe dan tujuan penelitian, maka sebelum menguji hipotesis, data akan dideskripsikan terlebih dahulu. Untuk menganalisis data dalam penelitian ini model struktural menggunakan analisis jalur (Path Analysis) Berikut adalah persamaan analisis jalur:

1. Pengujian Model 1

$Y=\alpha_{1}+\beta_{1} X 1+\beta_{2} X 2+\beta_{3} Z+\varepsilon$

2. Pengujian Model 2

$\mathrm{Z}=\alpha_{2}+\beta_{1} X 1+\beta_{2} X 2+\varepsilon$

Keterangan:

$\mathrm{Y} \quad=$ performance Guru

$\alpha=$ Konstanta

$\beta \quad=$ Koefisien regresi

$\mathrm{X} 1$ = Perilaku Kepemimpinan Visioner

$\mathrm{X} 2$ = Budaya Kerja

$\mathrm{Z} \quad=$ Iklim Kerja

$\varepsilon \quad=$ Tingkat Kesalahan (error)

\section{HASIL PENELITIAN}

\section{A. Deskripsi Variabel Penelitian}

\section{Variabel Perilaku kepemimpinan visioner kepala sekolah}

Perilaku kepemimpinan visioner kepala sekolah memiliki skor sebesar 76,89\% yang terletak pada kriteria yang cukup baik. Hal ini menunjukan bahwa kepala sekolah di SMP Negeri di Kabupaten Pohuwato memiliki kemampuan untuk berpikir lebih maju dalam upaya untuk meningkatkan kapasitas guru untuk mencapai hasil kerja yang lebih optimal. Makna visioner dari kepala sekolah ini apabila terus ditingkatkan dengan berbagai instrumen pengembangan secara internal maupun eksternal maka akan memberikan kontribusi yang baik bagi guru di sekolah. 


\section{Variabel Budaya kerja}

Budaya kerja memiliki skor sebesar $73,48 \%$ terletak pada kriteria yang cukup baik. Hal ini menunjukan bahwa SMP Negeri di Kabupaten Pohuwato memiliki budaya kerja yang baik yang dapat memberikan kenyamanan bagi guru dalam bekerja. Adanya budaya kerja yang kondusif dapat diciptakan oleh semua pihak di sekolah agar terjalin kerja sama antar guru dalam menyelesaikan tugas dan tanggung jawab sebagai pendidik.

\section{Variabel Iklim kerja}

Iklim kerja memiliki skor sebesar $76,74 \%$ yang terletak pada kriteria yang cukup baik. Hal ini menunjukan bahwa adanya iklim kerja yang kondusif di SMP Negeri di Kabupaten Pohuwato yang mampu mendorong guru untuk menjadi lebih aktif dalam bekerja dan mengajar karena iklim kerja yang kondusif menjadi koordinasi antara guru dan dengan kepala sekolah menjadi lebih intens dan berdampak positif dalam upaya untuk meningkatkan performance guru di sekolah

\section{Variabel performance guru}

Performance guru terletak pada kriteria yang baik dengan skor sebesar 78,09\%. Hal ini menunjukan bahwa guru di SMP Negeri di Kabupaten Pohuwato memiliki kemampuan dalam melaksanakan tugas dan tanggung jawabnya sebagai pendidikn baik dalam hal perencanan pembelajaran, pelaksanaan maupun evaluasi. Meski demikian, masih perlunya pembenahan bagi hasil kerja guru dalam melakukan evaluasi dalam kegiatan pembelajaran. Guru yang mampu mencapai hasil kerja yang optimal ini tentu akan memberikan dampak yang baik pula bagi peserta didik dan juga jenjang karir guru tersebut, sehingga performance guru harus terus ditingkatkan melalui berbagai tindakan aktual guru tersebut.

\section{B. Persamaan Pengaruh Langsung dan Tidak Langsung}

1. Pengaruh X1, X2 dan X3 Terhadap $Y$

Hasil analisis ditampilkan pada tabel 1 sebagai berikut:

Tabel 1: Pengaruh Langsung

\begin{tabular}{|c|c|c|c|c|c|}
\hline \multirow{2}{*}{ Model } & \multicolumn{2}{|c|}{$\begin{array}{l}\text { Unstandardized } \\
\text { Coefficients }\end{array}$} & \multirow{2}{*}{$\begin{array}{l}\text { Standardized } \\
\text { Coefficients } \\
\text { Beta }\end{array}$} & \multirow[t]{2}{*}{$\mathrm{t}$} & \multirow{2}{*}{ Sig. } \\
\hline & B & Std. Error & & & \\
\hline \multirow{4}{*}{$\begin{array}{l}\text { (Constant) } \\
1 \text { Kepemimpinan Visioner } \\
\text { Budaya Kerja } \\
\text { Iklim Kerja }\end{array}$} & 23.735 & 5.123 & & 4.633 & .000 \\
\hline & .659 & .139 & .362 & 4.732 & .000 \\
\hline & .644 & .105 & .329 & 6.159 & .000 \\
\hline & .737 & .180 & 296 & 4.097 & .000 \\
\hline
\end{tabular}

Sumber: Data olahan SPSS 21, 2019

Berdasarkan angka pada kolom Standardized Coefficients, maka persamaan struktural analisis jalurnya yakni sebagai beriku ini:

$\hat{\mathbf{Y}}=0,362 \mathrm{X}_{1}+0,329 \mathrm{X}_{2}+0,296 \mathrm{X}_{3}+\mathrm{e}$

\section{Pengaruh X1 dan X2 Terhadap X3} berikut:

Hasil analisis dengan bantuan program SPSS ditampilkan pada tabel sebagai 
Tabel 2: Pengaruh Tidak Langsung

\begin{tabular}{|c|c|c|c|c|c|}
\hline \multirow[t]{2}{*}{ Model } & \multicolumn{2}{|c|}{$\begin{array}{l}\text { Unstandardized } \\
\text { Coefficients }\end{array}$} & \multirow{2}{*}{\begin{tabular}{|l|}
$\begin{array}{l}\text { Standardized } \\
\text { Coefficients }\end{array}$ \\
Beta \\
\end{tabular}} & \multirow[t]{2}{*}{$\mathbf{t}$} & \multirow[t]{2}{*}{ Sig. } \\
\hline & B & Std. Error & & & \\
\hline (Constant) & 8.223 & 2.297 & & 3.579 & .000 \\
\hline 1 Kepemimpinan Visioner & .564 & .045 & .770 & 12.608 & .000 \\
\hline Budaya Kerja & .109 & .048 & .138 & 2.259 & .025 \\
\hline
\end{tabular}

Sumber: Data olahan SPSS 21, 2019

Berdasarkan angka pada kolom Standardized Coefficients, maka persamaan struktural analisis jalurnya yakni sebagai beriku ini:

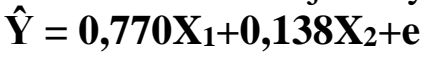

\section{Pengujian Analisis Jalur}

Berdasarkan analisis dapat disajikan pengaruh dari masing-masing variabel eksogen terhadap variabel endogen:

Tabel 3: Koefisien Jalur

\begin{tabular}{|c|c|c|c|c|c|}
\hline \multirow[b]{2}{*}{ Variabel } & \multicolumn{5}{|l|}{ Pengaruh } \\
\hline & Langsung & $\begin{array}{l}\text { Melalui } \\
\text { X1 }\end{array}$ & $\begin{array}{l}\text { Melalui } \\
\text { X2 }\end{array}$ & $\begin{array}{l}\text { Melalui } \\
\text { X3 }\end{array}$ & Total \\
\hline X1 ->Y & 0.131 & - & 0.089 & 0.094 & 0.314 \\
\hline X2 ->Y & 0.108 & 0.089 & - & 0.07 & 0.267 \\
\hline X3 ->Y & 0.088 & 0.094 & 0.07 & - & 0.251 \\
\hline X1 -> X3 & 0.770 & - & - & - & 0.770 \\
\hline $\mathrm{X} 2$-> X3 & 0.138 & - & - & - & 0.138 \\
\hline $\mathrm{R}^{2}(\mathrm{X} 1+\mathrm{X} 2+\mathrm{X} 3)$ & \multicolumn{5}{|l|}{0.832} \\
\hline $1-R^{2}$ & \multicolumn{5}{|l|}{0.168} \\
\hline
\end{tabular}

Sumber: Data Olahan SPSS 21, 2019

Berdasarkan tabel di atas dapat dilihat bahwa pengaruh secara keseluruhan yakni sebesar 0,832 yang menunjukan bahwa sebesar 83,20\% pengaruh dari perilaku kepemimpinan visioner kepala sekolah, budaya kerja dan iklim kerja terhadap performance guru di SMP Negeri di Kabupaten Pohuwato. Sementara sisanya sebesar 0,168 atau $16,80 \%$ dipengaruhi oleh faktor lain yang tdiak diteliti.

\section{Pengujian Hipotesis}

Adapun hasil pengujiannya dijabarkan pada tabel berikut ini:

Tabel 4: Hasil Pengujian Parsial

\begin{tabular}{|l|l|l|l|l|}
\hline Model & $\begin{array}{l}\text { Nilai Koefisien } \\
(\mathbf{t}-\text { Hitung }\end{array}$ & Signifikansi & tTabel & Keterangan \\
\hline $\mathbf{X 1}$->Y & 4.732 & 0.000 & 1,977 & Signifikan \\
\hline $\mathbf{X 2}$-> Y & 6.159 & 0.000 & 1,977 & Signifikan \\
\hline $\mathbf{X 3}$->Y & 4.097 & 0.000 & 1,977 & Signifikan \\
\hline $\mathbf{X 1}$-> X3 & 12.608 & 0.000 & 1,977 & Signifikan \\
\hline $\mathbf{X 2}$-> X3 & 2.259 & 0.025 & 1,977 & Signifikan \\
\hline
\end{tabular}

Sumber: Pengolahan Data SPSS 21, 2019 
1) Pengaruh Perilaku kepemimpinan visioner kepala sekolah, Budaya kerja dan Iklim kerja Terhadap performance guru

Adapun gambaran konstruk mengenai pengaruh perilaku kepemimpinan visioner kepala sekolah, budaya kerja dan iklim kerja terhadap performance guru disajikan sebagai berikut ini:

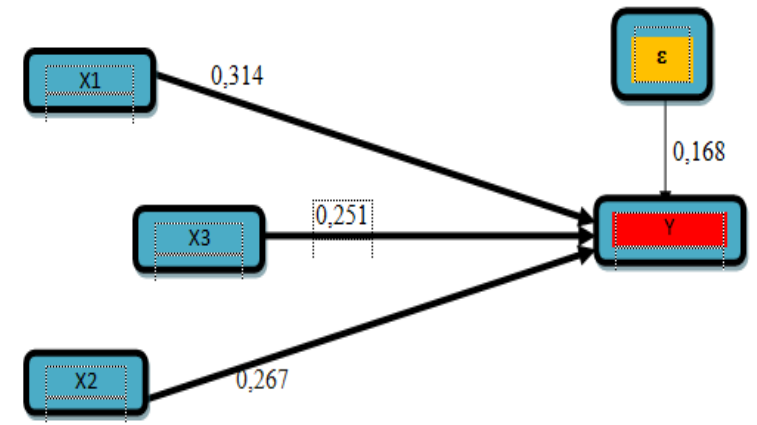

\section{Gambar 1: Struktur Pengaruh X1, X2 dan X3 Terhadap Y}

a) Pengaruh perilaku kepemimpinan visioner kepala sekolah terhadap performance guru

Nilai $t_{\text {hitung }}$ yang diperoleh jauh lebih besar dari nilai $t_{\text {tabel. }}$ Sehingga perilaku kepemimpinan visioner kepala sekolah berpengaruh positif dan signifikan terhadap performance guru di SMP Negeri di Kabupaten Pohuwato dengan nilai determinan sebesar $31,40 \%$.

b) Pengaruh Budaya kerja terhadap performance guru

Nilai $t_{\text {hitung }}$ yang diperoleh lebih besar dari nilai $t_{\text {tabel. }}$ Sehingga dengan demikian dapat disimpulkan bahwa budaya kerja berpengaruh positif dan signifikan terhadap performance guru di SMP Negeri di Kabupaten Pohuwato dengan nilai determinan sebesar $26,70 \%$.

c) Pengaruh Iklim kerja terhadap performance guru

Nilai thitung yang diperoleh jauh lebih besar dari nilai $t_{\text {tabel. }}$ Sehingga dengan demikian dapat disimpulkan bahwa iklim kerja berpengaruh positif dan signifikan terhadap performance guru di SMP Negeri di Kabupaten Pohuwato dengan nilai determinan sebesar $25,10 \%$.

\section{2) Pengaruh Perilaku kepemimpinan visioner kepala sekolah dan Budaya kerja terhadap Iklim kerja}

Adapun gambaran konstruk mengenai pengaruh perilaku kepemimpinan visioner kepala sekolah dan budaya kerja terhadap iklim kerja disajikan sebagai berikut ini: 


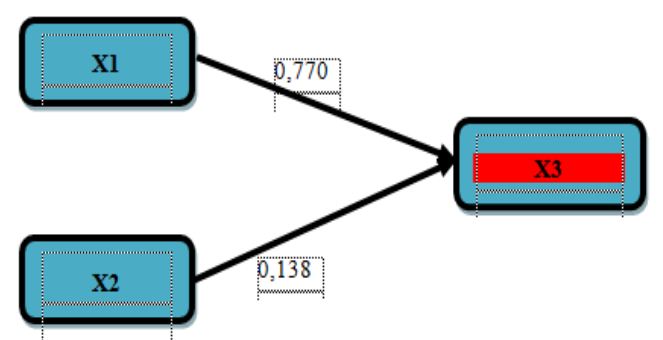

Gambar 2: Struktur Pengaruh X1 dan X2 Terhadap X3

\section{a) Pengaruh Perilaku kepemimpinan visioner kepala sekolah terhadap Iklim kerja}

Nilai thitung yang diperoleh jauh lebih besar dari nilai tabel. Sehingga dengan demikian dapat disimpulkan bahwa perilaku kepemimpinan visioner kepala sekolah berpengaruh positif dan signifikan terhadap iklim kerja di SMP Negeri di Kabupaten Pohuwato dengan nilai determinan sebesar $77,00 \%$.

b) Pengaruh Budaya kerja terhadap Iklim kerja

Nilai thitung yang diperoleh lebih besar dari nilai $t_{\text {tabel. }}$ Sehingga dengan demikian dapat disimpulkan bahwa budaya kerja berpengaruh positif dan signifikan terhadap iklim kerja di SMP Negeri di Kabupaten Pohuwato dengan nilai determinan sebesar $13,80 \%$.

\section{PEMBAHASAN}

\section{Pengaruh Perilaku kepemimpinan visioner kepala sekolah terhadap performance guru}

Hasil penelitian menunjukan bahwa nilai thitung untuk variabel Perilaku kepemimpinan visioner kepala sekolah sebesar 4,732. Jika dibandingkan dengan nilai $t_{\text {tabel }}$ yang sebesar 1,977. Maka thitung yang diperoleh jauh lebih besar dari nilai $t_{\text {tabel. }}$. Nilai signifikansi Perilaku kepemimpinan visioner kepala sekolah lebih kecil dari nilai probabilitas 0,05 , atau nilai $(0,000<0,05)$, maka perilaku kepemimpinan visioner kepala sekolah berpengaruh positif dan signifikan terhadap performance guru di SMP Negeri di Kabupaten Pohuwato. Kemudian dapat dilihat pada hasil perhitungan koefisien jalur ditemukan bahwa total pengaruh dari perilaku kepemimpinan visioner kepala sekolah terhadap performance guru di SMP Negeri di Kabupaten Pohuwato sebesar 31,40\%. Hasil ini sesuai dengan pendapat dari Hidayah (2016) bahwa keberhasilan sekolah dalam meningkatkan mutu pendidikannya, baik mutu akademik maupun non akademik sangat tergantung pada kepala sekolah untuk memimpin dengan visi.

Kepala sekolah yang senantiasa berorientasi pada masa depan sekolah akan cenderung mengupayakan adanya kinerja yang baik bagi warga skeolah yang dimpimpin. Sehingga dapat dikatakan perilaku kepemimpinan visioner kepala sekolah berpengaruh positif terhadap peningkatan perfomance guru.

Pentingnya kepemimpinan kepala sekolah dalam mengintervensi baiknya kinerja guru sangatlah krusial. Hal ini sebagaimana dikatakan oleh Muthohar (2016: 276) bahwa kepemimpinan visioner kepala sekolah sangat penting dimiliki oleh kepala sekolah dalam memprediksi tentang segala sesuatu yang berkaitan dengan kekuatankekuatan yang dimiliki, peluang-peluang yang ada, tantangan-tantangan yang harus 
dihadapi, ancaman-ancaman yang sekiranya muncul dalam memajukan lembaga pendidikan serta kemampuan dalam memengaruhi orang lain melalui interaksi individu dan kelompok sebagai wujud kerjasama dalam organisasi untuk mencapai tujuan yang telah ditetapkan secara efektif dan efisien

Hasil ini sesuai dengan pendapat dari Emmanouil, dkk (2013) bahwa sekolah telah diubah menjadi organisasi pembelajaran yang perlu terstruktur dengan baik dan memperbaharui dirinya secara terus-menerus dengan mempertimbangkan kebutuhannya saat ini dan masa depan. Kepemimpinan adalah mediator yang mengaktifkan inspirasi, motivasi, dukungan, dan bimbingan ke arah yang benar untuk memaksimalkan potensi guru dan mencapai peningkatan sekolah.

\section{Pengaruh Budaya kerja terhadap performance guru}

Hasil penelitian atas rumusan masalah kedua ditemukan bahwa nilai thitung untuk variabel Budaya kerja sebesar 6,159. Jika dibandingkan dengan nilai $t_{\text {tabel }}$ yang sebesar 1,977. Maka $t_{\text {hitung }}$ yang diperoleh lebih besar dari nilai $t_{\text {tabel. }}$ Nilai signifikansi Budaya kerja lebih kecil dari nilai probabilitas 0,05 , atau nilai $(0,000<0,05)$, maka budaya kerja berpengaruh positif dan signifikan terhadap performance guru di SMP Negeri di Kabupaten Pohuwato. Kemudian dapat dilihat pada hasil perhitungan koefisien jalur ditemukan bahwa total pengaruh dari budaya kerja terhadap performance guru di SMP Negeri di Kabupaten Pohuwato sebesar 26,70\%. Hal ini sejalan dengan pernyataan dari Putranto (2012: 11) bahwa semua organisasi mempunyai satu budaya yang bergantung pada kekuatannya. Budaya dapat mempunyai pengaruh yang bermakna pada sikap dan perilaku anggota-anggota organisasi dalam upaya pencapaian tujuan menghasilkan kinerja yang baik.

Hasil ini sesuai dengan temuan dari Selamat, dkk (2013) bahwa guru tidak dapat melaksanakan tugas mereka dan iklim organisasi di sekolah tidak sehat. Studi ini juga menunjukkan bahwa iklim organisasi ditemukan menjadi faktor signifikan yang dapat mempengaruhi kinerja guru. Dalam hal dimensi iklim organisasi, satu aspek dari perilaku kepemimpinan kepala sekolah dan perilaku guru: dorongan dan hambatan ditemukan menjadi faktor penting dalam meningkatkan kinerja guru

Hasil secara keseluruhan dari hipotesis kedua yakni budaya kerja berpengaruh positif dan signifikan terhadap performance guru. Hasil koefisien positif bermakna bahwa semakin sesuai budaya kerja yang diterapkan maka akan menunjang baiknya performance guru dalam menjalankan tanggung jawabnya. Untuk itu, pentingnya bagi sekolah dan warga sekolah untuk saling menjaga kerja sama, komunikasi dan koordinasi sebagai upaya untuk menciptakan budaya kerja dan iklim kerja yang kondusif dalam bekerja.

\section{Pengaruh Iklim kerja terhadap performance guru}

Hasil penelitian atas rumusan masalah ketiga ditemukan bahwa nilai $t_{\text {hitung }}$ untuk variabel Iklim kerja sebesar 4,097. Jika dibandingkan dengan nilai $t_{\text {tabel }}$ yang sebesar 1,977. Maka $t_{\text {hitung }}$ yang diperoleh jauh lebih besar dari nilai $t_{\text {tabel }}$. Nilai signifikansi Iklim kerja lebih kecil dari nilai probabilitas 0,05 , atau nilai $(0,000<0,05)$, maka iklim kerja berpengaruh positif dan signifikan terhadap performance guru di SMP Negeri di Kabupaten Pohuwato. Kemudian dapat dilihat pada hasil perhitungan koefisien jalur ditemukan bahwa total pengaruh dari iklim kerja terhadap performance guru di SMP 
Negeri di Kabupaten Pohuwato sebesar 25,10\%. Hasil tersabut sesuai dengan pendapat dari Redding dalam Hasanah (2010: 17) bahwa iklim komunikasi organisasi jauh lebih penting daripada keterampilan atau teknik-teknik komunikasi semata mata dalam menciptakan suatu organisasi yang efektif.

Hasil penelitian ini sejalan dengan temuan dari Utomo (2014) yang menemukan bahwa terdapat hubungan yang signifikan antara iklim komunikasi organisasi terhadap kinerja profesional guru. Sebuah kerja harus mempunyai misi menciptakan iklim kerja yang menantang dan menyenangkan, adil, kreatif, terintegratif, dan dedikatif terhadap pencapaian visi, menghasilkan lulusan yang berkualitas tinggi dalam perkembangan intelektualnya dan mempunyai karakter takwa, jujur, kreatif, mampu menjadi teladan, bekerja keras, toleran dan cakap dalam memimpin, serta menjawab tantangan akan kebutuhan pengembangan sumber daya manusia yang dapat berperan dalam perkembangan Iptek dan berlandaskan Imtak.

Sehingga dapat dikatakan bahwa iklim kerja memberikan pengaruh yang baik dan signifikan terhadap performance guru. Hasil koefisien positif bermakna bahwa semakin kondusif iklim kerja yang ada di sekolah maka akan semakin meningkat pula performance guru dalam menjalani tugasnya sebagai pendidik. Iklim kerja menjadi salah satu aspek yang sangat bermakna dalam menciptakan capaian kerja yang optimal dai segenap guru yang ada di sekolah sehingga akan tercipta kerja sama yang maksimal untuk kepentingan hasil kerja yang lebih baik kedepannya.

\section{Pengaruh Perilaku kepemimpinan visioner kepala sekolah terhadap Iklim kerja}

Hasil penelitian atas rumusan masalah keempat ditemukan bahwa nilai thitung untuk variabel Perilaku kepemimpinan visioner kepala sekolah sebesar 12,608. Jika dibandingkan dengan nilai $t_{\text {tabel }}$ yang sebesar 1,977 . Maka $t_{\text {hitung }}$ yang diperoleh jauh lebih besar dari nilai tabel. Nilai signifikansi Perilaku kepemimpinan visioner kepala sekolah lebih kecil dari nilai probabilitas 0,05 , atau nilai $(0,000<0,05)$, maka perilaku kepemimpinan visioner kepala sekolah berpengaruh positif dan signifikan terhadap iklim kerja di SMP Negeri di Kabupaten Pohuwato. Kemudian dapat dilihat pada hasil perhitungan koefisien jalur ditemukan bahwa total pengaruh dari perilaku kepemimpinan visioner kepala sekolah terhadap iklim kerja di SMP Negeri di Kabupaten Pohuwato sebesar 77,00\%. Hasil ini sesuai dengan pendapat dari Hidayah (2016) bahwa Agar tercapai visi dan misi sekolah secara efektif dan efisien maka sangat di butuhkan kepala sekolah yang memiliki karakter pemimpin yang visioner.

Wahjosumijo (2014) mengatakan bahwa iklim kerja yang kondusif ditandai dengan suasana kebersamaan, saling kerjasama dan sikap gotong royong antar anggota organisasi, sehingga organisasi terbebas dari suasana saling mencurigai dan saling memusuhi Apapun iklim yang hendak ditumbuhkan, seyogyanya iklim itu harus benar. Sebab, kepemimpinan dapat tumbuh berkembang dalam suatu iklim atau atmosfir kepercayaan. Misalnya seorang pemimpin akan mengalami kemunduran bila berada dalam iklim yang penuh ketidakpercayaan, kecurigaan, dan kesinisan. Maka secara otomatis iklim kerja guru jugaakan terpengaruhi sehingga dalam bekerja sangatlah lamban dan sering tidak fokus, maka untuk mencapai tujuan yang ditetapkan sebelumnya akan sulit. 
Hasil ini menunjukan bahwa perilaku kepemimpinan visioner kepala sekolah berpengaruh positif dan signifikan terhadap iklim kerja. Hasil koefisien positif bermakna bahwa pemimpin yang memiliki perilaku visioner akan mampu membuat sebuah iklim kerja yang kondusif bagi kenyamanan kerja kepala sekolah dan warga sekolah lainnya.

\section{Pengaruh Budaya kerja terhadap Iklim kerja}

Hasil penelitian atas rumusan masalah kelima ditemukan bahwa nilai thitung untuk variabel Budaya kerja sebesar 2,259. Jika dibandingkan dengan nilai $t_{\text {tabel }}$ yang sebesar 1,977. Maka thitung yang diperoleh lebih besar dari nilai $t_{\text {tabel. }}$ Nilai signifikansi Budaya kerja lebih kecil dari nilai probabilitas 0,05 , atau nilai $(0,025<0,05)$, maka budaya kerja berpengaruh positif dan signifikan terhadap iklim kerja di SMP Negeri di Kabupaten Pohuwato. Kemudian dapat dilihat pada hasil perhitungan koefisien jalur ditemukan bahwa total pengaruh dari budaya kerja terhadap iklim kerja di SMP Negeri di Kabupaten Pohuwato sebesar $13,80 \%$. Kecilnya pengaruh ini karena adanya gape yang seringkali terjadi di sekolah namun dengan adanya kebersamaan hal tersebut dapat diatasi. Hasil ini sesuai dengan pernyataan dari Putranto (2012: 11) bahwa semua organisasi mempunyai satu budaya yang bergantung pada kekuatannya, semakin baik budaya maka organisasi berserta pegawai didalamnya akan bekerja dengan baik pula.

Hasil penelitian dari budaya kerja terhadap ikiim kerja ini sejalan dengan temuan dari Emmanouil, dkk (2013) bahwa budaya kerja yang ditetapkan baik maka akan meningkatkan kondusifnya iklim kerja di sekolah.

Hasil pengaruh positif dan signifikan bermakna bahwa adanya budaya yang sesuai dalam bekerja maka akan tercipta sebuah iklim kerja yang mampu mendorong baiknya suasana kerja di sekolah. Hal ini menunjukan bahwa Budaya kerja menggambarkan bahwa sekolah sebagai organisasi yang memiliki budaya yang tumbuh karena diciptakan dan dikembangkan oleh individu- individu yang bekerja dalam suatu organisasi sekolah dan diterima sebagai nilai- nilai yang harus dipertahankan dan diturunkan kepada setiap anggota baru, nilai- nilai tersebut sebagai pedoman setiap anggota selama mereka berada dalam lingkungan organisasi tersebut dan dapat dianggap sebagai ciri- ciri yang dapat membedakan dengan sekolah lain.

\section{KESIMPULAN}

Berdasarkan hasil penelitian dan pembahasan di atas, maka dapat ditarik simpulan bahwa:

1. Perilaku kepemimpinan visioner kepala sekolah berpengaruh langsung positif dan signifikan terhadap performance guru SMP Negeri di Kabupaten Pohuwato.

2. Budaya kerja berpengaruh langsung positif dan signifikan terhadap performance guru SMP Negeri di Kabupaten Pohuwato.

3. Iklim kerja berpengaruh langsung positif dan signifikan terhadap performance guru SMP Negeri di Kabupaten Pohuwato.

4. Perilaku kepemimpinan visioner kepala sekolah berpengaruh langsung positif dan signifikan terhadap iklim kerja SMP Negeri di Kabupaten Pohuwato.

5. Budaya kerja berpengaruh langsung positif dan signifikan terhadap iklim kerja SMP Negeri di Kabupaten Pohuwato. 


\section{DAFTAR PUSTAKA}

Davis, Keith. 2007. Perilaku Dalam Organisasi. Jakarta: PT. Erlangga

Emmanouil, Konsolas; Anastasiou Osia MA and Loukeri Paraskevi-Ioanna. 2013. The Impact of Leadership on Teachers' Effectiveness. International Journal of Humanities and Social Science Vol. 4, No. 7(1)

Hasanah, Dedeh Sofia. 2010.. Pengaruh Latihan (Diklat) Kepeminpinan Guru dan Iklim Kerja Terhadap Kinerja Duru SD Se Kecamatan Babakan Cikao Kabupaten Purwakarta. Jurnal Penelitian Pendidikan Volume 11 No 2

Hidayah, Nurul. 2016. Kepemimpinan Visioner Kepala Sekolah dalam Meningkatkan Mutu Pendidikan. Yogyakarta: Ar-Ruzz Media.

Muthohar, Prim, Masrokan. 2016. Manajemen Mutu Sekolah. Stategi Peningkatan Mutu dan Daya Saing Lembaga Pendidikan Islam. Jogjakarta: Ar-Ruzz Media

Putranto, Agus Eko. 2012. "Pengaruh Budaya Organisasi Terhadap Efektivitas Kerja Pegawai Kantor Bagian Pemerintahan Kabupaten Tulungagung”. Jurnal "Otonomi" Vol. 12 No.1.

Selamat, Nurharani Nur Zahira Samsu dan Nur Shaminah Mustafa Kamalu. 2013. The Impact Of Organizational Climate On Teachers' Job performance. Educational Research eJournal ISSN 2254-0385 Faculty of Education. University of Alicante

Utomo, Sugeng Satrio. 2014. Hubungan kepemimpinan visioner, ketrampilan kepala sekolah dan iklim komunikasi organisasi terhadap kinerja profesional guru pada SMA Negeri di Kabupaten Malang. Tesis. Universitas Negeri Malang.

Wahjosumidjo. 2014. Kepemimpinan Kepala Sekolah Tinjauan Teoritikdan Permasalahannya. Jakarta: PT. Raja Grafindo Persada. 